\title{
Avaliação de Diferentes Alíquotas da Enxaguadura no Método Direto ISO 10272-2 Para A Contagem de Campylobacter spp. em Carcaças de Frango
}

\author{
Thalyta Marina Benetti (I), Wanda Moscalewski Abrahão (II,III), \\ Tereza Cristina Rocha Moreira Oliveira (I)
}

(I) UEL - Universidade Estadual de Londrina (Rod. Celso Garcia Cid (PR 445), Km 380 - Caixa Postal 10.011), (II) LACEN-PR - Laboratório Central do Estado do Paraná (Rua Amintas de Barros, 816 Bairro Alto da XV - Curitiba/PR CEP: 80.060-200), (III) UFPR - Universidade Federal do Estado do Paraná ( Av. Lothário Meissner, 632, CEP: 80210-170, Jardim Botânico, Curitiba - PR)

\section{Resumo}

A detecção e enumeração de Campylobacter spp. em carne de frango são essenciais para reduzir os riscos de contaminação. Muitos estudos associaram as dificuldades na contagem de Campylobacter em carne de frango à sua baixa competitividade frente à microbiota contaminante e à incapacidade dos agentes antimicrobianos adicionados aos meios seletivos de eliminar esta contaminação. O volume da enxaguadura utilizado no plaqueamento também pode levar a prejuízos na quantificação desse patógeno. O objetivo do presente estudo foi avaliar diferentes volumes de enxaguadura de carne de frango com a finalidade de minimizar a interferência da microbiota contaminante no isolamento e contagem de Campylobacter spp., sem comprometer a sensibilidade do método direto ISO 10272-2. Quarenta amostras de carcaças de frango resfriadas produzidas no Estado do Paraná foram coletadas em diferentes estabelecimentos comerciais da cidade de Curitiba, Paraná. O enxágue das carcaças foi realizado com adição de água peptonada tamponada a $0,1 \%$ (Oxoid) na proporção de $1 \mathrm{~mL}$ para cada grama de peso da carcaça, com fricção de toda a superfície. Alíquotas de 400, 100, 50, 10 e $5 \mu \mathrm{L}$ da enxaguadura foram semeadas em placas de Ágar carvão cefoperazona desoxicolato modificado (mCCDA) e Ágar Bolton modificado com incubação a $41,5 \pm 0,5^{\circ} \mathrm{C}$ por 48 horas em microaerofilia. Doze $(30,0 \%)$ das 40 amostras de carne de frango analisadas foram positivas para

\footnotetext{
Referência:

Thalyta Marina Benetti, Wanda Moscalewski Abrahão, Tereza Cristina Rocha Moreira Oliveira. Avaliação de Diferentes Alíquotas da Enxaguadura no Método Direto Iso 10272-2 Para A Contagem de Campylobacter spp. em Carcaças de Frango. In: Anais do 12 Congresso Latinoamericano de Microbiologia e Higiene de Alimentos - MICROAL 2014 [= Blucher Food Science Proceedings, num.1, vol.1]. São Paulo: Editora Blucher, 2014. 
Campylobacter spp. pelo método direto, quando volumes de 100 e $400 \mu \mathrm{L}$ de enxaguadura foram utilizados, contudo, apenas em seis (50\%) e em duas amostras $(16,7 \%)$ foi possível realizar a contagem, quando utilizado os respectivos volumes. Nos demais volumes, 50,10 e $5 \mu \mathrm{L}$, somente foi possível a detecção e quantificação em 4 (33,3\%), $3(25,0 \%)$ e $1(8,3 \%)$ das 12 amostras positivas, respectivamente. A estratégia de utilização de volumes menores que $100 \mu \mathrm{L}$ de enxaguadura não melhorou o isolamento e a contagem de colônias de Campylobacter. Esses resultados, portanto, confirmam que o volume de enxaguadura mais adequado para o método direto é o de $100 \mu \mathrm{L}$, como o preconizado na metodologia ISO 10272-2. Assim, uma provável solução para minimizar a interferência da microbiota contaminante seria desenvolver novos meios seletivos ou incorporar aos já existentes outros antimicrobianos.

Palavras-Chave: Campylobacter spp., quantificação, ISO 10272-2: 2006, carcaça de frango resfriada

\section{Agência de Fomento:}

